\title{
高次脳機能障害 一検査の進め方
}

\author{
前 島 伸一郎 ${ }^{*}$ 大 沢 愛 子* 宮 㠃 泰 広 ${ }^{*}$
}

\begin{abstract}
要旨：高次脳機能評価に必要な検査の進め方について解説を行った。患者の病状を正確に把握する ためにも, 適切な検査と詳細な観察，そして正しい解釈が必要である。高次脳機能障害は神経心理 学的検査の成績だけでなく，患者が具体的にどのような課題に対して，どのように反応したかとい う過程が重要である。患者の日常生活や社会生活を念頭におき，患者や家族の声を傾聴する姿勢が 何より大切である。
\end{abstract}

(高次脳機能研究 $30 （ 2 ） ： 299 ＼mathrm{~ 307 ， 2010 ） ~}$

Key Words : 高次脳機能障害, 神経心理学的検査, 言語療法

higher brain dysfunction, Neuropsychological tests, speech therapy

\section{はじめに}

脳損傷患者を診療する際は, 意識障害や運動麻 痺の程度を把握するのと同じように，高次脳機能 障害を評価し，常に病状を把握するように努める べきである。高次脳機能障害は注意してみなけれ ば, ベテランの医療スタッフですら, 気がつかな いこともある。一見して正常な患者でも日常生活 場面でさまざまな問題を生じることもあるが，患 者は自分の病状に関して無関心であったり，過度 にストレスを感じたりする。また，身体機能障害 が軽度で, 慣れた環境内での身の回りの動作は自 立していても, 記憶, 遂行機能, 情緒, 行動などの 障害のために, 就労や就学などの社会参加に至ら ない場合も少なくない。このため，病院にいる間 から, 退院後の生活を考えて高次脳機能障害の評 価と治療を行うべきである。本稿では, 高次脳機 能評価に必要な検査の進め方について解説を行う。

\section{I . 検查の目的}

医療者が患者の状態を熟知することは，当然の 職務であり, 意識障害や運動麻疩の程度を把握す るのと同じょうに, 高次脳機能障害を評価し, 常 に病状を把握するように努めるべきである。高次
脳機能障害を詳細に評価することによって, 病巣 部位の推定が容易になり, 病態を把握することが 可能となる。たとえば, CT や MRI などでは十分 描出できない脳病変を, 高次脳機能を詳細に評価 することによって検出できる場合も少なくない。 このような場合でも, 病態と Single photon emission CT (SPECT) や Positron emission tomography (PET) で得られた機能的病変が一致することが少 なくないため, 補助診断として, より詳細な機能 画像検査が必要である。また, 高次脳機能障害を 詳細に評価することにより, 日常生活場面での問 題点や社会生活を遂行する上での注意点を明らか にすることが可能である。さらに，予後の推定や， 回復過程の評価, 訓練効果の判定などに用いるこ ともできる（Maeshimaら 1997a，1997b，2000）。

\section{II. 神経心理学検査を行う前に}

病歴・現症などを確認しながら, 診察が進めら れ, 必要に応じて, 血液検査や画像検査, 生理機 能検査, 神経心理学的検查などが施行される（図 1)。高次脳機能障害が疑われる場合には，まず検 查器具を使わずに, 比較的短時間で大まかな障害 の有無を把握することが必要である。高次脳機能 障害を自覚している患者はそれほど多くはない。 


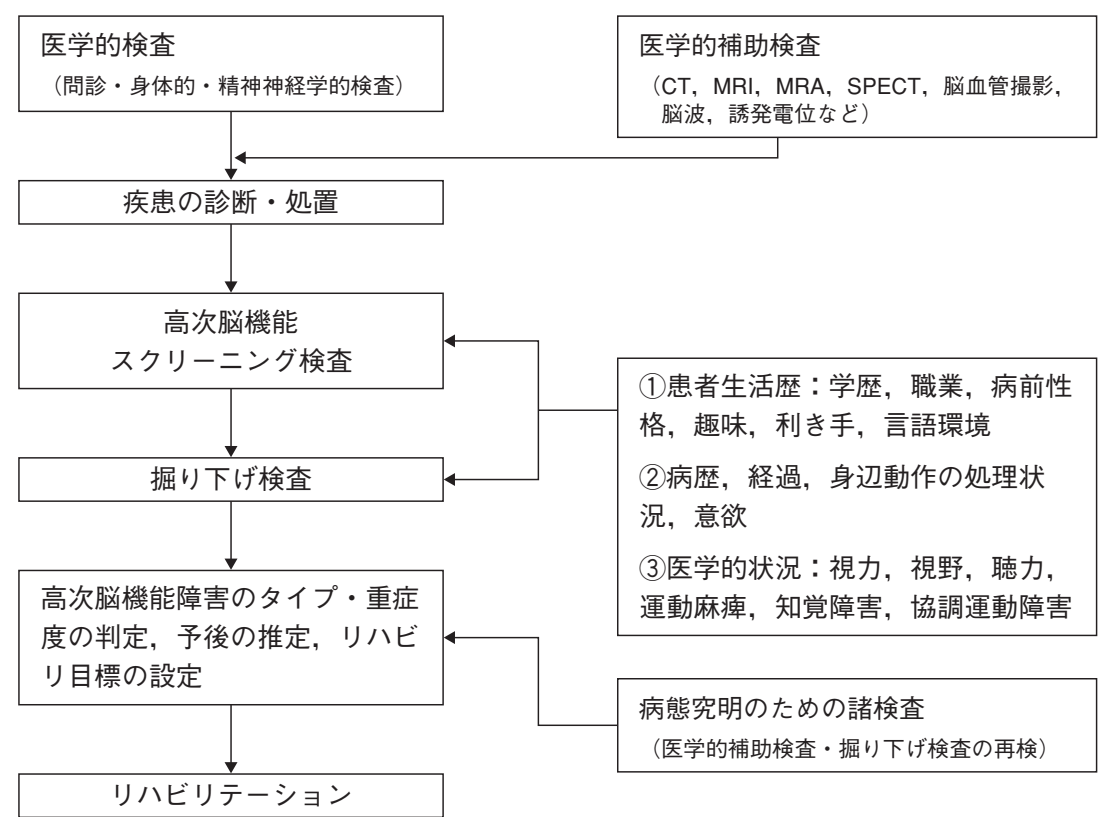

図1 高次脳機能検査の進め方

診察場面で指摘すると, 患者自身がその障害に気 付くこともあるが，認識できないことも少なくな い。患者の付き添いや看護師などの観察者の言動 にも注意を払い, 日常生活での異常について尋ね る。問診に際して必要なことは, 病前の状態を把 握することである。何より, 利き手に関する情報 を事前に得ておくことは, 脳の側性化と病巣の関 係を論ずる上で重要である。Kerteszら（1981）の 方法では, 書く, 投げる, 切る, 描く, 歯を磨く, スプーン (箸)を使う，の 6 項目の中で 4 項目に該 当した側を利き手とする。エディンバラ利き手調 查（Oldfield 1971）では 12 項目から利き手度 (Laterality Quotient) を判定する方法である。利き 手と言語に関する優位脳は必ずしも一致しないが, 右半球損傷で失語症をきたした場合 (前島ら 1992) や左半球損傷で右半側空間無視をきたした場合 (Maeshimaら 1992) には, 予後を推測する上で 有用な情報である（図 2,3）。幼少時に矯正され たことがないか, 家族の利き手・矯正歴について も聴取しておく。意識障害のある急性期や失語が ある場合は，患者自身からの情報聴取は難しいの で，あらかじめ家族から情報を得ておく。なお，
大脳皮質に手術侵襲が及ぶ可能性がある場合，術 前よりあらかじめアミタールテスト（木下ら 1996） や機能的 MRI を用いて言語機能の側性化を明確に しておくべきである。

一方，教育歴（年数）も，病前の脳機能を知る 上では欠かせない情報である。教育年数が長い人 ほど, 肺癌, 大腸癌, 乳癌, 前立腺癌による死亡 率が低いことや，短い人ほど，認知症になりやす い，うつになりやすいなどが指摘されている。ま た，教育年数が影響を与える神経心理検査もある ために注意が必要である。日常臨床で初対面の患 者に，学歴を尋ねることは，たやすいことではな いが，コミュニケーションの一手段として「二十 歳の頃は何をしていましたか?」と尋ねるなどの 工夫をすれば，容易に聴取できる（前島ら 2005b)。

脳卒中の発症直後は意識障害やせん妄などを伴 うことが多い（前島ら 2005a, 森ら 1987, 田渕ら 2004b)。この場合, 高次脳機能障害の質や重症度 を正確に評価することは難しい。また，急性期は しばしば症状に変動がみられるため，一度の診察 だけでは見落としてしまうこともあり，検査の反 


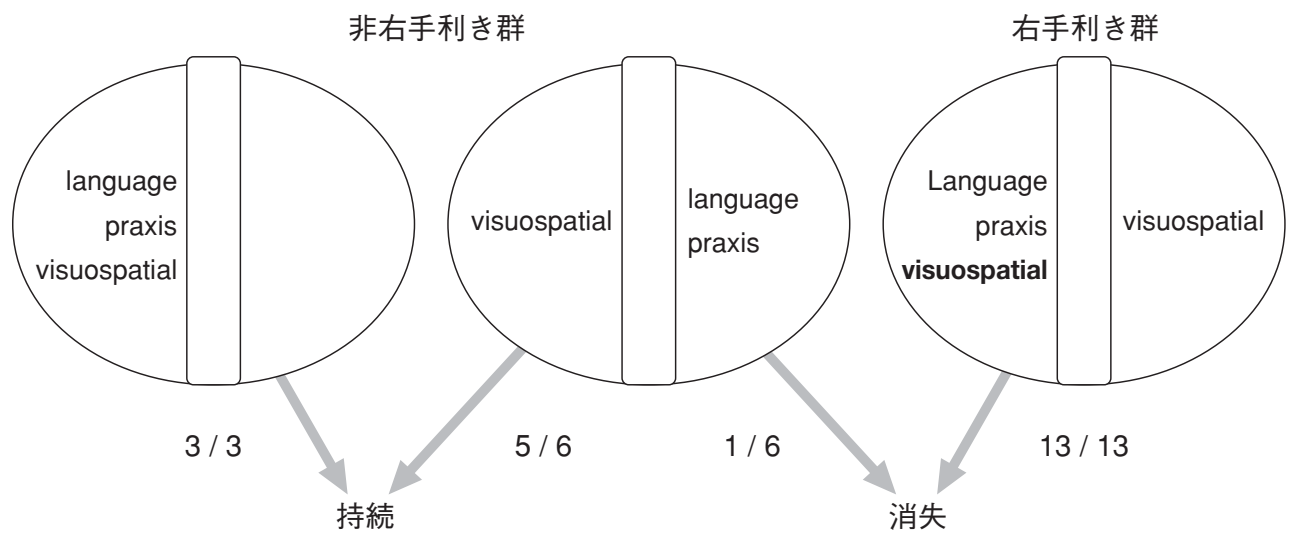

図 2 右半側空間無視の臨床経過

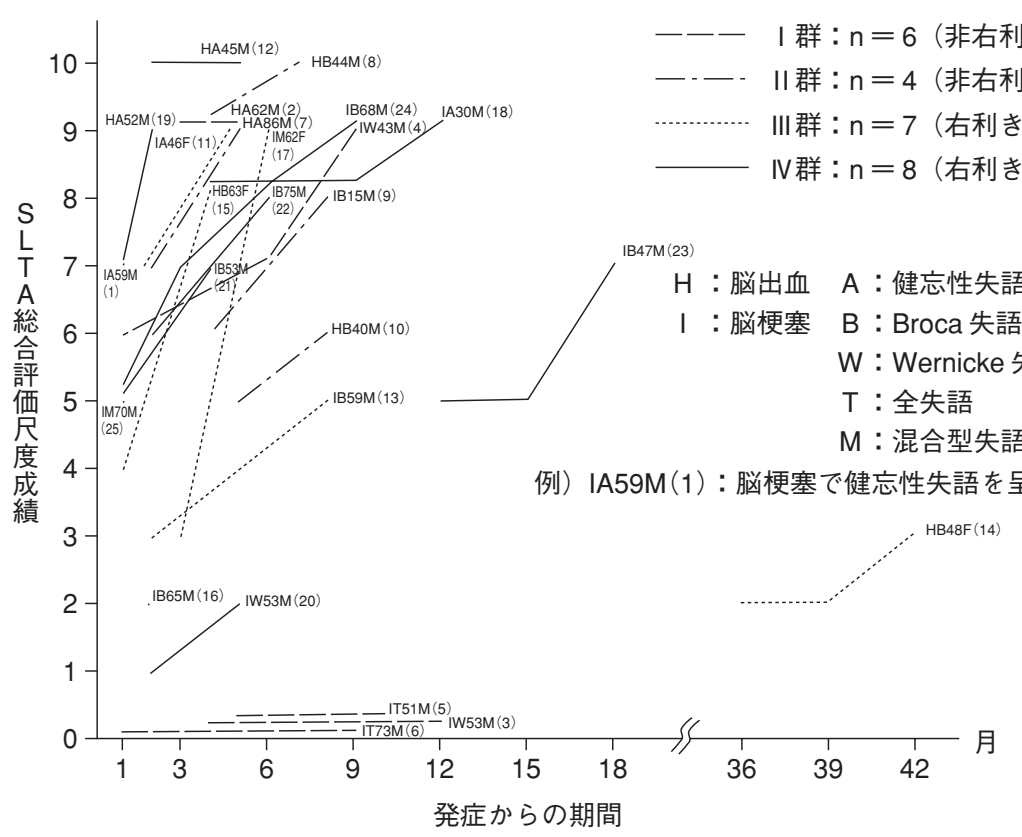

図 3 右半球損傷による失語症の経過 一 SLTA 総合評価尺度成績の経時的変化一

(前島伸一郎, 重野幸次, 種村 純, ほか：右大脳半球損傷による失語症の検討一特に利き手に よる言語症状の相違について。リハビリテーション医学, $29: 517-526,1992$ より許諾を得て転載)

復施行も必要となる。加えて, 注意障害, 疲労, うつ状態，意欲などの非特異的脳機能障害や精神 症状が評価に大きな影響を与えることもあるので 注意が必要である（鹿島 2007, 田渕ら 2004b）。 高次脳機能障害を適切に評価するためには, 患者 から最高の達成水準を引き出すことが必要であり, そのためには適正な検査状況を設定しなければな
らない（鹿島 2007）。この際, もっとも大切なこ とは, 患者との信頼関係, あるいは人間関係であ る(石合 2003)。神経心理学的検査には患者の協 力が不可欠であり, 興味本位で「何かの障害を見 つけ出してやろう」という態度は論外である。患 者や家族との関わりの中で，「何とか意志疎通を図 りたい」,「生活上で何か問題はないだろうか？」, 
「職場で困ることはないか？」などということを一 緒に明らかにし，その問題について対応していき たいとする前向きな姿勢が大切である（石合 2001)。

\section{III. 神経心理学的検査の選び方}

高次脳機能障害については, 種々の神経心理学 的検査を組み合わせて, 系統的, 定量的に検査を 行い，障害を全体的にとらえる必要がある（表 1）。 多くのデー夕に基づき標準化された検査法やバッ テリー結果はスコアとして定量的に得られ，検査 の妥当性は健常者や脳損傷者から得られた定量的 データの統計的解析により保証されている。検査 手技は定式化されており, 検者の経験や能力にあ まり関係せず，検査の信頼性も高い。しかし，教
示の方法によって異なる反応が得られる場合も少 なくない（Ishiaiら 1997）。したがって，個々の検 査の施行の順序, 時に標準的な検査手続きの枠を 越えて検査することや, 練習効果などにも留意す べきである（鹿島 2007）。ただし，市販の検査を すべて行えば良いというのではなく，患者の状態 や病状を理解し，目的を明確にした上で必要な検 査を選び出す必要がある。リハビリテーション医 学の立場からは，障害された機能を調べるだけで はなく, 残存能力を明らかにすることが大切であ る。この観点から, 定量化されて得たスコア (IQ や得点）よりも，定性的デー夕（問題に対し，ど のように取り組み，解決したか）が，重要になる こともしばしばであるため，検査施行中の患者の 反応に注意し，十分な記録を残して詳細に解析す

表 1 神経心理学的検査

\begin{tabular}{|c|c|}
\hline 知能 - 精神機能 & $\begin{array}{l}\text { WAIS-III } \\
\text { WISC-III } \\
\text { 長谷川式簡易痴呆診査スケール } \\
\text { Mini-mental state examination（MMSE） } \\
\text { Kohs 立方体組み合わせテスト } \\
\text { レーヴン色彩累進マトリックス検査（RCPM） }\end{array}$ \\
\hline 記憶 & $\begin{array}{l}\text { Wechsler Memory Scale Revised（WMS-R） } \\
\text { Rivermead Behavioral Memory Test（RBMT) } \\
\text { Benton 視覚記銘検查（BVRT） } \\
\text { Rey-Osterreith複雑図形（ROCFT） } \\
\text { Auditory Verbal Learning Test（AVLT） } \\
\text { 三宅式対語記憶検査 } \\
\text { ハノイの塔 }\end{array}$ \\
\hline 行為·認知 & $\begin{array}{l}\text { 標準高次動作性検査（SPTA） } \\
\text { 標準高次視知覚検査（VPTA） } \\
\text { 日本語版 BIT 行動性無視検査（BIT） }\end{array}$ \\
\hline 言語 & $\begin{array}{l}\text { 標準失語症検査（SLTA） } \\
\text { WAB 失語症検査（WAB） }\end{array}$ \\
\hline その他 & $\begin{array}{l}\text { Wisconsin Card Sorting Test（WCST） } \\
\text { 語想起検査（WFT） } \\
\text { Trail Making Test（TMT） } \\
\text { 仮名ひろいテスト } \\
\text { Frontal Assessment Battery（FAB） }\end{array}$ \\
\hline
\end{tabular}

太字：標準化された検査（教示を含む実施要領, 正常值, 判定基準· 例などが記載されたマニュアルを含む，正式なセット） 
る必要がある。

\section{IV．神経心理学的検查の実際}

Mini-Mental State Examination (MMSE) (Folstein ら 1975, 森ら 1985）や改訂版長谷川式簡易知能 評価スケール（HDS-R）（加藤ら 1991）, 仮名ひ ろいテスト（金子 1990）, Frontal assessment battery (FAB) (Dubois ら 2000, 前島ら 2006a, 高 木ら 2002), レーヴン色彩マトリックス検査 （RCPM）（大沢ら 2006c, Raven 1976，杉下ら 1993）は非常に簡便な神経心理学的検査である。 数〜十分程度で施行でき, 大まかな認知機能の異 常を評価できるが，失語症や半側空間無視，注意 障害などの影響を受けやすい。MMSEや FAB, RCPM は世界中で広く利用されているため, 他国 データとの比較も可能である。なお, MMSEや HDS-Rでは，ほとんどが言語性の項目であり， 非言語性の認知機能は評価し難いため, その解釈 には RCPMのような非言語性検査を組み合わせる などの工夫が必要である。また, 類似した問題で あっても, 各々の検査によってオリジナルの教示 が異なるため，あらかじめ原著を熟読した上で， 評価を行うべきである。

失語症の評価には，標準失語症検査（SLTA） (日本高次脳機能障害学会 (旧日本失語症学会) 2003) や WAB 失語症検査日本語版（WAB 失語症 検査 (日本語版) 作成委員会 1986）が用いられる。 いずれも, 口頭言語の理解, 発話, 音読, 復唱, 文字言語の理解, 書字, 計算などの項目からなる。 これらの失語症検査を用いて, 言語機能全般につ いて把握した後は, 必要に応じて, 掘り下げテス 卜を行う。言語理解を評価するためにToken Test がしばしば用いられるが，漢字・仮名テストや復 唱テストなど標準化されていない検査法も少なく ない。一方，失語症患者の残存能力を評価するた めには言語を介さない検査を用いる。後述のウェ クスラー成人知能検査 (Wechsler Adult Intelligence Scale：WAIS）の動作性 IQ や RCPM，ベントン 視覚記銘検査 (BVRT)（アーサーLベントン 1985） などの非言語性検査は失語症があっても比較的容 易に施行できる。

失行症の評価には, 標準高次動作性検査 (SPTA)
（日本失語症学会 1985）が一般的に用いられる。 これは, 顔面動作, 慣習的動作, 手指構成模倣, 客体のない動作, 連続動作, 着衣動作, 物品を使 う動作, 系列的動作, 下肢・物品を使う動作, 描 画, 積み木など 13 の大項目, 45 の小項目からな る。また, WAB 失語症検査にも行為の下位項目が ある。失語症があっても, 模倣や物品を用いれば, 評価は可能である。

失認症の評価には, 高次視知覚検査 (VPTA) （日本失語症学会 1997）が用いられる。これは視 覚の基本機能, 物体 - 画像認知, 相貌認知, 色彩 認知, シンボル認知, 視空間認知と走査, 地誌的 見当識など 7 の大項目, 44 の小項目からなる。半 側空間無視の評価では諸外国でもよく使用されて いる BIT 行動性無視検査の日本版 (BIT 日本語版 作成委員会 1999）が用いられる。これは机上で行 う検査ではあるが, 従来の線分抹消検査や二等分 検查に加え, メニュー読み, 文の朗読, 時計合わ せ課題など日常での無視による行動異常を推察す べく開発されたものである。半側空間無視患者で は, WAIS の動作性 IQ, RCPM, BVRT, ROCFT などの視覚性検査で明らかな低下を示すが，言語 性 IQ の保たれていることが多く, MMSEや HDS -Rだけでは気づかないこともある。

もっとも標準的かつ代表的な知能検査である WAIS は現在, 改訂 3 版（WAIS-III）（日本版 WAIS-III刊行委員会 2006）が用いられている。検 查は 6 つの言語性知能に関する下位検査（知識, 数唱, 単語, 算数, 理解, 類似) と 5 つの非言語 性知能に関する下位検査（絵画完成，絵画配列， 積木模様，行列推理，符号）から構成されている。 該当する年齢群の平均值を 100 , 標準偏差を 15 と した標準データに照らし合わせ, 言語性知能指数 (IQ), 動作性 IQ, 全 IQ の他, 言語理解, 知覚統 合，作動記憶，処理速度などの指数を算出できる。

記憶の検査は, Auditory Verbal Learning Test (AVLT) (大沢ら 2006b, Rey 1964) や三宅式対語記 銘力検査 (三宅式), ベントン視覚記銘検査 (BVRT) (アーサーLベントン 1985), Rey-Osterriethの複 雑図形（ROCFT）（前島ら 2007, Rey 1941）など が，簡便に用いられる。AVLTは 15 個の単語を聞 かせた後, 被験者にその単語の自由再生を行わせ 
るもので, 即時記憶容量を測定して, 学習曲線を 示し，記憶障害の特性を明らかにすることができ る。三宅式は互いに関連のある 10 対の単語と, 関 連のない 10 対の単語を, それぞれ 3 回ずつ記銘さ せる検査である。BVRTは10枚のカードに描かれ た図柄を再生 (即時, 遅延), 模写させる検査であ る。ROCFTは長さの異なる 34 本の線分と, 内部 に 3 つの点を持つ円からなる図柄を模写させた後 に再生させるものであり, 記憶のみならず, 視覚 性認知, 視空間構成, 運動機能などを抽出する。 記憶検査の多くは，主に記銘力を評価するもので あり，記憶能力のすべてを評価しているものでは ないため注意が必要である。すなわち, 個人の体 験（エピソード記憶）や技能（手続き記憶）を評 価しているわけではない。また，失語症では AVLT や三宅式のような言語性検査が著明に低下 し, 半側空間無視や構成障害があれば BVRTや ROCFT のような視覚性検査は低下する。したがっ て, 記憶を評価する際は, あらかじめ日常場面で どのように問題であるかを聞き出しておくことが 大切である。なお, 記憶に関する総合的な検査と して, 改訂版ウェクスラー記憶尺度（Wechsler Memory Scale-Revised）が用いられる。これは, 13 種類の下位検査の結果から, (1)言語性記憶, (2) 視覚性記憶, (3)一般的記憶, (4)注意/集中力, (5) 遅延再生の 5 種類を指数として算出される（杉下 2001)。最近, 日本版リバミード行動記憶検査 (Rivermead Behavioural Memory Test) がしばしば 用いられる (数井ら 2002, 前島ら 2006b, 綿森ら 2002）が，これは人の姓名や顔, 約束, 用件, 道 順など，日常生活に準拠した記憶を評価する。4 種類の異なるバッテリーがあるため繰り返し行う ことができる。

さて，前頭前野に局所的な損傷が認められた場 合，言語や視空間認知に異常を認めず，記憶や知 能指数の低下を認めないことがある。しかし, 臨 床症状として, 発動性の低下や常同行為, 保続, 思考障害, 社会行動障害などさまざまな症状を呈 する（Damasio ら 1993）ことが知られており, 最 近は種々の前頭葉機能検査法が用いられる。 Wisconsin Card Sorting Test（WCST）（鹿島ら 1993, 加藤 1988） は概念あるいはセットの転換と
維持に関する能力を評価するもので, 色, 数, 形 の異なる図形が描かれた 4 枚のカードの下に， 1 枚ずつカードを提示し， 3 種のカテゴリーのいず れかに従ってカードを分類していく。本邦では慶 應版 WCSTが普及しており，脳ドックなどでパー ソナルコンピュータを用いた評価が行われている。 WCST は前頭葉背外側部の損傷例で成績低下がみ られる。Modified Stroop Test（鹿島ら 1993）は書 かれた色名とは異なる色が塗られたカードが提示 され，そのカードを読まずに色名を答えるという 日常習慣的活動を抑制する課題である。遂行機能 障害症候群の行動評価法（Behavioural Assessment of the Dysexecutive Syndrome）（田渕ら 2004a）は 6 種類の下位検査と 1 つの質問表から構成されて おり，さまざまな行動面の障害を系統的かつ包括 的に評価する方法である。言語流暢性検査は指示 されたカテゴリーの単語をできるだけ多く述べる 意味カテゴリー流暢性課題とそれぞれの文字から 始まる単語をできるだけ多く述べる文字流暢性課 題がある。言語流暢性検査（大沢ら 2006a，斉藤 ら 1992）は，軽度認知症を同年齢の健常老人から 鑑別する上で有効である。Trail Making Test（鹿 島ら 1986) は2 種類のパートからなる視覚探索運 動課題で，Part A では紙面にランダムに配置され た数字を順に, Part B では数字と文字を交互に線 で結んでいく。この際，Part Aでは，注意の持続 と選択，Part B ではさらに注意や概念の変換能力 が要求される。なお, これらの検査には, 遂行機 能の一定の側面を評価するものがあり，同義的に 使われるものも多い。

\section{まとめ}

高次脳機能障害の評価に際して, 適切な検査と 詳細な観察，そして正しい解釈を行わなければ, 患者の病状を正確には把握できない。高次脳機能 障害は神経心理学的検査の成績だけでなく, 患者 が具体的にどのような課題に対して，どのように 反応したかという過程が何より大切である。患者 の日常生活や社会生活を念頭におき，家族の声を 傾聴する姿勢が何より大切である。 


\section{文献}

1 ) アーサー Lベントン, 著, 高橋剛夫, 訳 : ベン トン視覚記銘検查使用手引。増補 2 版，三京房， 京都， 1985.

2 ) BIT 日本語版作成委員会：BIT 行動性無視検査日 本語版。新興医学出版, 東京, 1999.

3 ) Damasio, A. R. \& Anderson, S. W. : The frontal lobes. Clinical Neuropsychology (eds Heilman, K. M. \& Valenstein, E.). 3rd Ed., Oxford University Press, New York, 1993, pp. 409-460.

4 ) Dubois, B., Slachevsky, A., Litvan, I., et al. : The FAB ; A frontal assessment battery at the bedside. Neurology, 55 : 1621-1626, 2000.

5 ) Folstein, M. F., Folstein, S. E. \& McHugh, P. R. : "Mini-Mental State" ; a practical methods for grading the cognitive state of patients for clinician. J. Psychiatr. Res., 12 : 182-198, 1975.

6 ) Ishiai, S., Seki, K., Koyama, Y., et al. : Disappearence of unilateral spatial neglect following a simple instruction. J. Neurol. Neurosurg. Psychiatry, $63: 23-27,1997$.

7 ) 石合純夫：失語・失行・失認の治療. Medicina, $38:$ 1351-1352, 2001.

8 ) 石合純夫：高次脳機能障害の診察一基礎知識一. 高次脳機能障害学. 医蒾薬出版, 東京, 2003, pp. $1-24$.

9 ）鹿島晴雄, 半田貴士, 加藤元一郎, ほか：注意 障害と前頭葉損傷。神経研究の進歩, 30：847858, 1986.

10）鹿島晴雄，加藤元一郎：前頭葉機能検査一障害 の形式と評価法. 神経研究の進歩, 37：93-110, 1993.

11）鹿島晴雄 : 認知症の神経心理学的検査一神経心 理学的検查の問題点について. 老年精神医学雑 誌，18（臨増）：51-57, 2007.

12）加藤元一郎：前頭葉損傷における概念の形成と 変換について一新修正 Wisconsin card sorting test を用いた検討。慶應医学, $65 ： 861-885,1988$.

13）加藤伸司, 長谷川和夫, 下垣 光, ほか：改訂
長谷川式簡易知能評価スケール（HDS-R）の作 成. 老年精神医学雑誌, $2 ： 1339-1347,1991$.

14）金子満雄：痴呆と前頭葉機能. 失語症研究, 10 ： 127-131, 1990.

15）数井裕光, 綿森淑子, 本多留実, ほか：日本版 リバミード行動記憶検査（RBMT）の有用性の検 討。神経進歩，46：307-317, 2002.

16) Kertesz, A. \& Sheppard, A. : The epidemiology of aphasic and cognitive impairment in stroke ; age, sex, aphasia type and laterality differences. Brain, $104: 117-28,1981$.

17）木下泰伸, 前島伸一郎, 寺田友昭, ほか：Super Selective Amytal Testの試み一less invasive な診 断を目指して一。脳神経, 48：1121-1125, 1996 。

18）前島伸一郎，重野幸次，種村 純，ほか：右大 脳半球損傷による失語症の検討一特に利き手に よる言語症状の相違について。リハビリテーシ ョン医学, 29 : 517-526, 1992.

19) Maeshima, S., Truman, G., Smith, D. S., et al. : Functional outcome following thalamic haemorrhage. Disability and Rehabilitation, 19 : 459464, 1997a.

20) Maeshima, S., Terada, T., Yoshida, N., et al. : Cerebral angioplasty in a patient with vascular dementia. Arch. Phys. Med. Rehabil., 78 : 666$669,1997 \mathrm{~b}$.

21) Maeshima, S., Truman, G., Smith, D. S., et al. : Apraxia and cerebral haemorrhage : the relationship between haematoma volume and prognosis. J. Clin. Neurosci., 7 ： 309-311, 2000.

22) Maeshima, S., Shigeno, K., Dohi, N., et al. : A study of right unilateral spatial neglect in left hemisphere lesions ; the difference between righthanded and non-right-handed post-stroke patients. Acta. Neurol. Scand., 85 ： 418-424, 1992.

23）前島伸一郎, 大沢愛子, 種村 純：脳卒中亜急 性期の言語障害. Journal of Clinical Rehabilitation (臨床リ八), $14 ： 58-62,2005 a$.

24）前島伸一郎，大沢愛子：教育年数を聴取する秘 
訣. 神経内科, $62: 307,2005 b$.

25）前島伸一郎, 種村 純, 大沢愛子, ほか：高齢 者に打ける Frontal assessment battery (FAB) の臨 床意義について。脳と神経, 58：207-211,2006a.

26）前島伸一郎，種村 純，大沢愛子，ほか：高齢 者における展望的記憶の検討一とくに存在想起 と内容想起の違いについて一. リハビリテーシ ョン医学, 43：446-453, 2006b.

27）前島伸一郎, 大沢愛子, 太田信子, ほか：ReyOsterriethの複雑図形を用いた認知症者の視覚性 記憶の検討. 老年精神医学雑誌, $18 ： 411-416$, 2007.

28）三村 將: 高次脳機能障害とその問題点一精神 科の立場から. 高次脳機能研究, $22: 185-192$, 2002.

29）森 悦朗, 山鳥 重, 三谷洋子: 急性右中大脳 動脈領域梗塞における行動神経学的症候群。神 経心理学, 3 ：198-208, 1987.

30）森 悦朗, 三谷洋子, 山鳥 重: 神経疾患患者 における日本語版 Mini-Mental State テストの有 用性. 神経心理学, 1：82-90, 1985.

31）日本版 WAIS-III刊行委員会：WASI-III成人知能 検查. 日本文化社, 東京, 2006 .

32) 日本高次脳機能障害学会 (旧 日本失語症学会), 編：標準失語症検査マニュアル，改訂第二版， 新興医学出版, 東京, 2003.

33）日本失語症学会, 編：標準高次動作性検査 失 行症を中心として。医学書院, 東京, 1985.

34）日本失語症学会, 編：標準高次視知覚検査。新 興医学出版, 東京, 1997.

35) Oldfield, R. C. : The assessment and analysis of handedness ; the Edinburgh inventory. Neuropsychologia, 9 : 97-113, 1971.

36) 大沢愛子, 前島伸一郎，種村 純，ほか：もの 忘れ外来に打ける認知症と言語流暢性課題. 高 次脑機能研究, $26 ： 327-333,2006$ a.

37）大沢愛子, 前島伸一郎, 種村 純, ほか：もの 忘れ外来を受診した高齢者の言語性記憶に関す
る研究. 高次脳機能研究, $26: 320-326,2006 b$.

38) 大沢愛子, 前島伸一郎, 種村 純, ほか：もの 忘れを有する患者における Raven’s colored progressive matrices と Mini-mental State Examination. 日本老年精神医学誌, $17 ： 435-440,2006 c$.

39) Raven, J. C. : Coloured progressive matrices. Oxford Psychologists Press, London, 1976.

40) Rey, A. : L'examen clinique en Psychogie. Presses Universitaires de France, Paris, 1964.

41) Rey, A. : Lexamen psychologique ; Dans les cas d'encephalopathie traumatique (Les problemes). Arch. Psychol., 28 : 286-340, 1941.

42) 斉藤寿昭, 加藤元一郎, 鹿島晴雄, ほか：前頭 葉損傷と Word Fluency一特に抑制障害との関連 について. 失語症研究, $12 ： 223-231,1992$.

43）杉下守弘, 山崎久美子：日本版レーヴン色彩マ トリックス検査 手引。日本文化科学社, 東京, 1993.

44）杉下守弘：ウェクスラー記憶検査日本語版。日 本文化科学社, 東京, 2001 .

45）田㴊 肇, 鹿島晴雄：遂行機能障害の評価法. 臨床リハ別冊／高次脳機能障害のリハビリテー ションVer. 2 (江藤文夫, 武田克彦, 原 寞美, ほ か, 編). 医茵薬出版，東京， 2004a, pp. 176-181.

46）田㴊 肇, 鹿島晴雄 : 認知機能障害の診断と評 価法. 脳と循環，9：23-27, 2004b.

47）高木理恵子, 梶本賀義, 神吉しづか, ほか：前 頭葉簡易機能検査（FAB）一パーキンソン病にお ける検討一。脳神経, 54：987-902, 2002.

48) WAB 失語症検查（日本語版）作成委員会, 編 : $\mathrm{WAB}$ 失語症検査（日本語版）。医学書院, 東京, 1986.

49）綿森淑子, 原 寛美, 宮森孝史, ほか：日本版 リバミード行動記憶検査（RBMT)。千葉テスト センター, 東京, 2002.

50) Wechsler, D. : The measurement of adult intelligence. Williama \& Wilkins, Baltimore, 1939, p. 229. 


\section{Abstract}

\section{Procedure of neuropsychological tests for patients with higher brain dysfunction}

\section{Shinichiro Maeshima* Aiko Osawa* Yasuhiro Miyazaki*}

This paper discusses the required inspection procedures for evaluation of higher brain function. In order to obtain the accurate status of a patient, an appropriate inspection, a detailed observation and a correct interpretation of it are necessary. For higher brain dysfunction, it is a matter of importance that not only results of neuropsychological test should be shown but also the processes during which how a patient reacts specifically to what issue should be grasped. Among other things, the most important approach is to listen attentively to opinions of patients' family members with the patients' daily living and social life in view. 